\title{
THE USE OF DIELECTRIC HONEY FEATURES FOR OVERHEATING DIAGNOSTICS
}

\author{
D. ŁuCZYCKA a and K. PENTOŚ*a \\ ${ }^{a}$ Institute of Agricultural Engineering, Wroclaw University of Environmental and Life Sciences, \\ ul. J. Chełmońskiego 37/41, 51-630 Wrocław. Poland
}

(Received: 5 December 2017; accepted: 12 May 2018)

\begin{abstract}
During processing operations, honey can be exposed to excessive heat. That adversely affects the quality of product (its biological activity). The aim of this work was to test the possibilities of the use of dielectric properties (relative permittivity and dielectric loss coefficient) for honey overheating detection. Nine honey types obtained directly from beekeepers were investigated. Honey was heated at the temperatures $60,70,80$, and $90{ }^{\circ} \mathrm{C}$ for 24 hours and then cooled down to $25-26^{\circ} \mathrm{C}$. At that temperature, dielectric properties of biological material under study were determined. In the frequency range $400 \mathrm{~Hz}$ to $4 \mathrm{kHz}$, the significant influence of thermal treatment temperature on both dielectric parameters was observed. Both dielectric parameters decrease as the heating temperature increases. The statistical analysis suggested that dielectric parameters can be used for distinguishing honey overheated from not overheated. Therefore, they can be potentially useful for honey quality assessment according to its overheating, e.g. in co-packing process. The proper frequency range for these parameters measurement is $1-4 \mathrm{kHz}$.
\end{abstract}

Keywords: dielectric properties, honey quality, honey overheating

Food processing operations have a significant effect on products quality. Food adulteration caused mostly by economic reasons is nowadays a constantly growing problem (SILVIS et al., 2017). Therefore, quick and cheap methods of food quality assessment are developed and implemented instead of time-consuming methods based usually on chemical analyses.

Honey is a natural food produced by honey bees from the nectar of plants or from honeydew. Honey consists mainly of sugars but also of other minor compounds such as minerals, phenolic compounds, organic acids, amino acids, protein, vitamins, and enzymes (SAXENA et al., 2010; DA Silva et al., 2016), and its positive influence on human health is well proven (Bogdanov et al., 2008; KAVAPURAYIL et al., 2014). Packaging conditions, preservation methods, and storage time affect honey properties, therefore, only appropriately harvested, processed, and stored product retains its nutritional potential.

Normally, honey is not commercialized in its raw state. During the processing, it is commonly the subject of thermal treatment in two stages. The first stage comprises preheating at approx. $55{ }^{\circ} \mathrm{C}$ for honey liquefaction, straining, and clarification. The second stage is pasteurisation at approx. $80^{\circ} \mathrm{C}$ to dissolve sugar crystals, inactivate spoilage microorganisms and undesirable enzymes, and facilitate packing (Escriche et al., 2014; FAUZI et al., 2014). Nevertheless, thermal treatment at the temperature above $40{ }^{\circ} \mathrm{C}$ results in adverse changes to honey properties such as brown turbidity, undesired flavour, or decrease of biological activity. The effect of heating up to $90{ }^{\circ} \mathrm{C}$ is decrease of total phenolic compounds and antioxidant activity (Kowalski, 2013; Chaikham \& Prangthip, 2015). Honey type influences also the

\footnotetext{
* To whom correspondence should be addressed.

Phone: +48 71 3205970; fax: +48 71 3482486; e-mail: katarzyna.pentos@upwr.edu.pl
} 
behaviour of diastase activity during thermal treatment. It was stated by SAMBORSKA and CZELEJEWSKa (2014) that honey diastase activity decreases with temperature increase in the $50-90{ }^{\circ} \mathrm{C}$ range differently in multifloral and rape honey. According to BABACAN and RAND (2007), the complete inactivation of amylase is the result of honey heated for $2 \mathrm{~min}$ at $71^{\circ} \mathrm{C}$ or $8 \mathrm{~min}$ at $63{ }^{\circ} \mathrm{C}$. Small reduction in invertase activity was the effect of honey thermal treatment at the temperature $45{ }^{\circ} \mathrm{C}$ (less than $20 \%$ ). However, the pasteurisation process induces a decrease in invertase activity of about $90 \%$ (BONVEHI et al., 2000). In many papers, accumulation of 5-hydroxymethylfurfural (HMF) as a result of honey overheating is reported (Chaikham et al., 2016). The increase in HMF content is also the effect of long storage time. TURHAN and co-workers (2008) suggest that the excessive HMF content might be related to primitive storage conditions rather than overheating. According to KARABOURNIOTI and ZERVALAKI (2001), the combination of HMF and invertase should be used in order to detect the honey exposure to heat. However, it is worth emphasizing that all chemical parameters mentioned above can only be tested by a specialist laboratory.

Some researchers stated that electrical properties can be used for food quality assessment (Guo et al., 2010; Pentoś et al., 2015; Karuppuswami et al., 2017; Valantina et al., 2017). GuO and co-workers (2011) found relationship between the temperature and honey dielectric properties in the frequency range from 10 to $4500 \mathrm{MHz}$. Similar results were reported by PASZKOwsKi and co-workers (2014) at the frequency below $2 \mathrm{MHz}$. Electrical honey properties seem to be promising as honey overheating indicators.

The aim of the present research was to determine the influence of thermal treatment temperature on honey electrical parameters: relative permittivity $\varepsilon$ and dielectric loss coefficient tg $\delta$ in the frequency range from $10 \mathrm{~Hz}$ to $1 \mathrm{MHz}$.

\section{Materials and methods}

\subsection{Materials}

Honey samples harvested in the year 2011 from May to September, derived directly from beekeepers located in Lower Silesia region (Poland), were used for this study. A total of nine samples were analysed: linden flower (Tilia spp.), rapeseed (Brassica napus L.), phacelia (Phacelia tanacetifolia Benth.), buckwheat (Fagopyrum esculentum Moench), heather (Calluna vulgaris L.), willow (Salix spp.), multiflower, and honeydew. For the verification of honey types, a pollen analysis was accomplished in an accredited laboratory (Bee Products Quality Testing Laboratory in Puławy, Poland). Pollen analysis was conducted according to harmonized methods of melissopalynology, particularly according to Polish Standard PN88/A-77626, paragraph 5.3.18. Additionally, the classification of honey sample as the honeydew honey was based on the value of conductivity of $20 \%$ honey aqueous solution (electrical conductivity higher than $0.8 \mathrm{mS} \cdot \mathrm{cm}^{-1}$ is required for honeydew honey). The percentage content of pollen in honey samples is detailed in Table 1.

Honey samples were fresh, without a thermal treatment or improper storage. The water content of honey samples was determined by the refractometric method with the use of refractometer PAL-22S (dedicated to honey water content measurement). The water content of honey samples varied from $14.2 \%$ to $17.2 \%$. Samples were stored at the temperature of $10-12{ }^{\circ} \mathrm{C}$ until analysis. In Table 2 , the selected chemical properties of honey samples are presented. These properties were measured with the use of the methods compiled by the International Honey Commission (BogDanov et al., 1997). 
Table 1. The percentage concentration of pollen in honey samples (only pollen content exceeding $10 \%$ is presented)

\begin{tabular}{|c|c|c|c|c|c|c|c|c|c|c|c|}
\hline $\begin{array}{l}\text { Honey } \\
\text { sample }\end{array}$ & $\begin{array}{c}\text { Brassica } \\
\text { napus }\end{array}$ & $\begin{array}{c}\text { Phace- } \\
\text { lia }\end{array}$ & $\begin{array}{c}\text { Bras- } \\
\text { sicaceae }\end{array}$ & $\begin{array}{c}\text { Fag- } \\
\text { opyrum }\end{array}$ & Salix & $\begin{array}{l}\text { Trifo- } \\
\text { lium }\end{array}$ & $\begin{array}{l}\text { Soli- } \\
\text { dago }\end{array}$ & Calluna & Echium & Tilia & Prunus \\
\hline Rapeseed & 74.43 & & & & & & & & & & \\
\hline Phacelia & & 80.64 & & & & & & & & & \\
\hline Buckwheat & & & 43.84 & 13.31 & 13.45 & & & & & & \\
\hline Honeydew & & & 24.48 & & & 16.12 & & & & & \\
\hline Multiflower & & 32.42 & 16.44 & & & & 23.22 & & & & \\
\hline Heather & & & & 10.67 & & & & 73.39 & & & \\
\hline Willow & & & & & 84.83 & & & & & & \\
\hline $\begin{array}{l}\text { Linden } \\
\text { flower }\end{array}$ & & & 27.82 & & & & & & 21.46 & 30.84 & \\
\hline Multiflower & 65.51 & & & & & & & & & & 20.26 \\
\hline
\end{tabular}

Table 2. Chemical characteristics of honey samples

\begin{tabular}{lccccc}
\hline $\begin{array}{l}\text { Honey } \\
\text { sample }\end{array}$ & $\begin{array}{c}\text { Glucose content } \\
(\mathrm{g} / 100 \mathrm{~g})\end{array}$ & $\begin{array}{c}\text { Fructose content } \\
(\mathrm{g} / 100 \mathrm{~g})\end{array}$ & $\begin{array}{c}\text { HMF (Hydroxy- } \\
\text { methylfurfural }) \\
\text { content }\left(\mathrm{mg} \mathrm{kg}^{-1}\right)\end{array}$ & $\begin{array}{c}\text { Diastase activity } \\
\text { (Schade units })\end{array}$ & $\begin{array}{c}\text { Proline } \\
(\mathrm{mg} / 100 \mathrm{~g})\end{array}$ \\
\hline Rapeseed & 40.5 & 35.6 & 16.8 & 33.0 & 42.3 \\
Phacelia & 40.4 & 31.8 & 12.6 & 16.8 & 37.9 \\
Buckwheat & 39.3 & 33.2 & 15.0 & 65.8 & 44.4 \\
Honeydew & 37.9 & 32.3 & 19.9 & 21.8 & 53.3 \\
Multiflower & 38.5 & 33.7 & 25.5 & 35.2 & 41.4 \\
Heather & 38.2 & 30.0 & 4.2 & 69.3 & 45.1 \\
Willow & 39.5 & 34.1 & 15.0 & 21.6 & 33.0 \\
Linden & 39.9 & 29.3 & 3.6 & 18.9 & 30.3 \\
flower & 36.5 & 29.3 & 5.2 & 20.3 \\
Multiflower & & & & 21.6 \\
\hline
\end{tabular}

\subsection{Heating procedure}

For the experiment, honey samples were thermally treated for 24 hours in climatic chamber at temperatures $60,70,80$, and $90^{\circ} \mathrm{C}$. As a reference, honey samples heated to temperature $26^{\circ} \mathrm{C}$ were analysed. After thermal treatment, samples were cooled down to $25-26^{\circ} \mathrm{C}$ (in the climatic chamber, in which the further measurements were taken). Both honey heating and cooling were conducted at the air humidity of $40 \%$. Measurement of honey dielectric parameters was conducted directly after the cooling procedure (in less than one hour).

\subsection{Determination of honey dielectric parameters}

Measurements of honey impedance have been taken with the ATLAS 0441 HIA apparatus (impedance analyzer) and cylindrical electrode system. The impedance was represented as real and imaginary parts:

$$
Z=\operatorname{Re} Z+j \cdot \operatorname{Im} Z
$$

where $Z$ is complex impedance, $R e Z$ is the real part of impedance, and $\operatorname{Im} Z$ is the imaginary part of impedance. 
The frequency range was set as $10-10^{6} \mathrm{~Hz}$, measurement voltage was set as $100 \mathrm{mV}$. The measurements were conducted with 5 measurement points per decade on a logarithmic scale (26 measurement points in the whole frequency range). As the result, an arithmetic mean of three consecutive measurements was taken. Based on impedance values, relative permittivity $\varepsilon(-)$ and dielectric loss coefficient $\operatorname{tg} \delta(-)$ were calculated as follows:

$$
\begin{gathered}
\operatorname{tg} \delta=\frac{\operatorname{ReZ}}{\operatorname{ImZ}}, \\
\varepsilon=\frac{\mathrm{C}}{C_{\mathrm{p}}}
\end{gathered}
$$

where $C$ is capacitance of capacitor (cylindrical electrode) with honey sample $(\mathrm{F}), C_{\mathrm{p}}$ is capacitance of empty capacitor $(\mathrm{F})$. The capacitance $\mathrm{C}$ was calculated according to the following equation:

$$
C=\frac{B}{\omega}=\frac{B}{2 \cdot \Pi \cdot f}=\frac{\frac{-I m Z}{\left(R e Z^{2}+I m Z^{2}\right)}}{2 \cdot \Pi \cdot f}
$$

where B is susceptance (S), $\omega$ is angular frequency $\left(\operatorname{rad~s}^{-1}\right)$.

\subsection{Statistical analysis}

Correlations were established using Pearson's correlation coefficient (r). Dependence of honey dielectric features on the three factors, namely frequency, honey type, and thermal treatment temperature, were determined using three way analysis of variance (ANOVA) followed by Tukey's honestly significant difference (HSD) post hoc test, when the data followed a normal distribution. The distribution of data was evaluated by the KolmogorovSmirnov and Shapiro tests. A $\mathrm{p} \leq 0.05$ was considered statistically significant. Statistical analyses were carried out with Statistica v.10 environment (StatSoft, Poland).

\section{Results and discussion}

As is presented in Table 2, the HMF content, an indicator of the thermal treatment of honey samples, was found to be in the range of $3.6 \mathrm{mg} \mathrm{kg}^{-1}$ to $25.5 \mathrm{mg} \mathrm{kg}^{-1}$, which is lower than the internationally recommended limit of $80 \mathrm{mg} \mathrm{kg}^{-1}$ (CODEX Alimentarius Commission, 2001). In the analysed samples, the proline content varied from a minimum of $20.3 \mathrm{mg} / 100 \mathrm{~g}$ to a maximum of $53.3 \mathrm{mg} / 100 \mathrm{~g}$. Only one sample (multiflower) did not comply with the recommended limit of minimum $25 \mathrm{mg} / 100 \mathrm{~g}$ according to Polish Standard PN-88/A-77626 "Honey". The diastase activity in honey samples was from 16.8 to 69.3 Schade units, which is in agreement with internationally recommended limit of minimum 8 Schade units (CODEX Alimentarius Commission, 2001). In order to determine how physicochemical honey parameters are related to dielectric features, Pearson's correlation coefficients were calculated (Table 3). The values of dielectric parameters measured at the frequency of $1.1 \mathrm{kHz}$ and at the temperature of $26^{\circ} \mathrm{C}$ were used for calculations.

Generally, linear correlations between physicochemical and dielectric honey parameters are very low and statistically insignificant. Only correlation between relative permittivity and fructose content is relatively high $(-0.81)$. 
Table 3. Correlation coefficients between physicochemical and dielectric honey parameters

\begin{tabular}{|c|c|c|c|c|c|c|c|}
\hline & $\begin{array}{l}\text { Glucose } \\
\text { content }\end{array}$ & $\begin{array}{c}\text { Fructose } \\
\text { content }\end{array}$ & $\begin{array}{c}\text { HMF } \\
\text { content }\end{array}$ & $\begin{array}{c}\text { Diastase } \\
\text { activity }\end{array}$ & Proline & $\begin{array}{c}\text { Dielectric } \\
\text { loss } \\
\text { coefficient }\end{array}$ & $\begin{array}{c}\text { Relative } \\
\text { permittivity }\end{array}$ \\
\hline Glucose content & 1.00 & 0.23 & -0.21 & -0.37 & -0.63 & -0.56 & -0.45 \\
\hline Fructose content & 0.23 & 1.00 & 0.75 & -0.12 & 0.17 & -0.61 & -0.81 \\
\hline HMF content & -0.21 & 0.75 & 1.00 & -0.22 & 0.40 & -0.51 & -0.68 \\
\hline Diastase activity & -0.37 & -0.12 & -0.22 & 1.00 & 0.39 & 0.44 & 0.29 \\
\hline Proline & -0.63 & 0.17 & 0.40 & 0.39 & 1.00 & 0.27 & 0.03 \\
\hline $\begin{array}{l}\text { Dielectric loss } \\
\text { coefficient }\end{array}$ & -0.56 & -0.61 & -0.51 & 0.44 & 0.27 & 1.00 & 0.93 \\
\hline $\begin{array}{l}\text { Relative } \\
\text { permittivity }\end{array}$ & -0.45 & -0.81 & -0.68 & 0.29 & 0.03 & 0.93 & 1.00 \\
\hline
\end{tabular}

Numbers in bold indicate statistically significant correlations $(\mathrm{P}<0.05)$.

The preliminary statistical analysis (ANOVA) revealed the significant influences of the temperature of thermal treatment, frequency, and honey type on dielectric loss coefficient $\operatorname{tg} \delta$. In the case of relative permittivity $\varepsilon$, results of the analysis of variance do not show the influence of thermal treatment temperature over the entire frequency range (Table 4).

Table 4. Results of ANOVA for dielectric loss coefficient $\operatorname{tg} \delta$ and relative permittivity $\varepsilon$, for frequency $10 \mathrm{~Hz}-1 \mathrm{MHz}$

\begin{tabular}{lccc}
\hline Source of variation & Degrees of freedom d.f. & ANOVA F-ratio & Significance level \\
\hline Dielectric loss coefficient tg $\delta$ & 8 & & 0.0000 \\
Type of honey & 5 & 7.3355 & 0.0000 \\
Temperature & 25 & 5.3332 & 0.0000 \\
Frequency & & 61.7180 & 0.0000 \\
Relative permittivity $\varepsilon$ & 8 & & 0.5051 \\
Type of honey & 5 & 4.1694 & 0.0000 \\
Temperature & 25 & 0.8633 & 5.9303 \\
Frequency & & & \\
\hline
\end{tabular}

The dependence between dielectric parameters of multiflower honey and a frequency is presented in Figure 1.

For further analysis, the frequency range of $400 \mathrm{~Hz}-4 \mathrm{kHz}$ was chosen. In this frequency range, the significant influence of thermal treatment temperature on both dielectric parameters was observed (Table 5).

More detailed information than presented in Table 5 was provided by the Tukey's HSD post-hoc tests and the analysis of interaction effects. The Tukey's HSD post-hoc tests revealed that for dielectric parameters, significant difference between honey no thermally processed and honey heated up was observed $(\mathrm{p}=0.000017$ for $\operatorname{tg} \delta$ and $\mathrm{p} \leq 0.000040$ for $\varepsilon$ ). However, these parameters can be useful only for distinguishing honey overheated from not overheated, but not for distinguishing eg. honey overheated up to $60{ }^{\circ} \mathrm{C}$ from honey overheated up to $80{ }^{\circ} \mathrm{C}$. The analysis of Tukey's test results in the case of honey types suggests that some 
samples are similar according to tg $\delta$, eg. willow and rapeseed $(\mathrm{p}=0.998)$ or buckwheat and rapeseed $(\mathrm{p}=0.749)$ and $\varepsilon$, e.g. honeydew and rapeseed $(\mathrm{p}=0.999)$ or buckwheat and rapeseed $(\mathrm{p}=0.946)$.
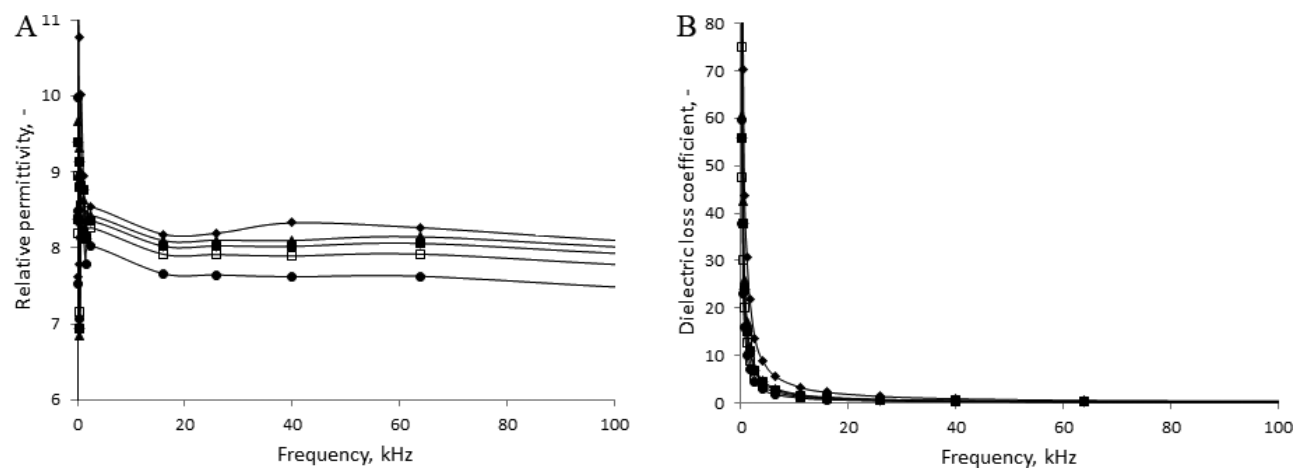

Fig. 1. Multiflower honey relative permittivity $\varepsilon$ (A) and dielectric loss coefficient $\operatorname{tg} \delta(\mathrm{B})$, as affected by frequency, for honey thermally treated at various temperatures $\left({ }^{\circ} \mathrm{C}\right)$

$\neg: 26 ; \multimap-: 60 ; \rightarrow-: 70 ; \square-: 80 ; \multimap-: 90$

Table 5. Results of ANOVA for dielectric loss coefficient tg $\delta$ and relative permittivity $\varepsilon$, for frequency $400 \mathrm{~Hz}-4 \mathrm{kHz}$

\begin{tabular}{lccc}
\hline Source of variation & Degrees of freedom d.f. & ANOVA F-ratio & Significance level \\
\hline Dielectric loss coefficient tg $\delta$ & 8 & 120.9392 & \\
Type of honey & 5 & 25.0750 & 0.0000 \\
Temperature & 5 & 72.1536 & 0.0000 \\
Frequency & & & 0.0000 \\
Relative permittivity $\varepsilon$ & 8 & 47.415 & \\
Type of honey & 5 & 13.020 & 0.0000 \\
Temperature & 5 & 5.837 & 0.0000 \\
Frequency & 5 & & 0.0000 \\
\hline
\end{tabular}

The analysis of interaction effects revealed that in the case of dielectric loss coefficient, interaction effect frequency $\times$ thermal treatment $(\mathrm{F}=0.244$ and $\mathrm{p}=0.999)$ as well as honey type $\times$ thermal treatment temperature $(\mathrm{F}=0.360$ and $\mathrm{p}=0.998)$ are not statistically significant. It can be stated that $\operatorname{tg} \delta$ can be useful for overheating detection when measured in the whole frequency range $(400 \mathrm{~Hz}$ to $4 \mathrm{kHz})$ and for all honey types under study.

The presence of statistically significant interaction effect of honey type $\times$ thermal treatment temperature $(\mathrm{F}=3.324$ and $\mathrm{p}=0.000000)$ for relative permittivity suggests that the use of these parameters for honey overheating detection can be difficult. This problem requires further analysis with the use of more honey samples.

The nature of the relationship between both $\operatorname{tg} \delta$ and $\varepsilon$ and frequency is similar for honey thermally treated at different temperatures (Fig. 2). More significant differences in $\operatorname{tg} \delta$ and $\varepsilon$ values between samples thermally treated at various temperatures are observed for lower frequencies. The value of $\operatorname{tg} \delta$ as well as the range of $\operatorname{tg} \delta$ values decrease as the frequency increases. 

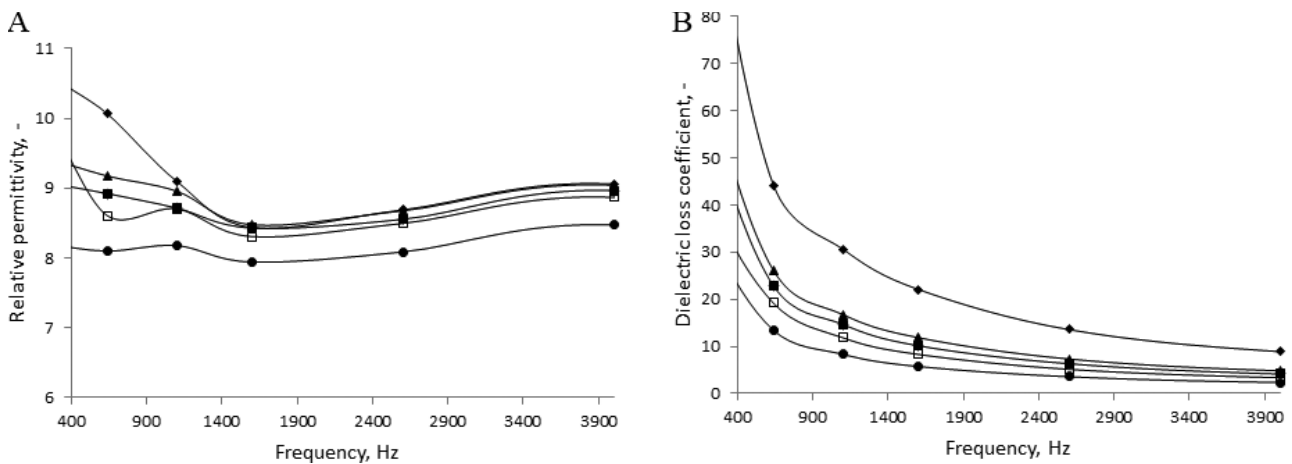

Fig. 2. Phacelia honey relative permittivity $\varepsilon(\mathrm{A})$ and dielectric loss coefficient $\operatorname{tg} \delta(\mathrm{B})$, as affected by frequency, for honey thermally treated at various temperatures $\left({ }^{\circ} \mathrm{C}\right)$

$\neg:: 26 ; \multimap: 60 ; \multimap-: 70 ;-\square-: 80 ; \multimap-: 90$

Analogical results were obtained for dielectric parameters measured for other honey types under investigation.
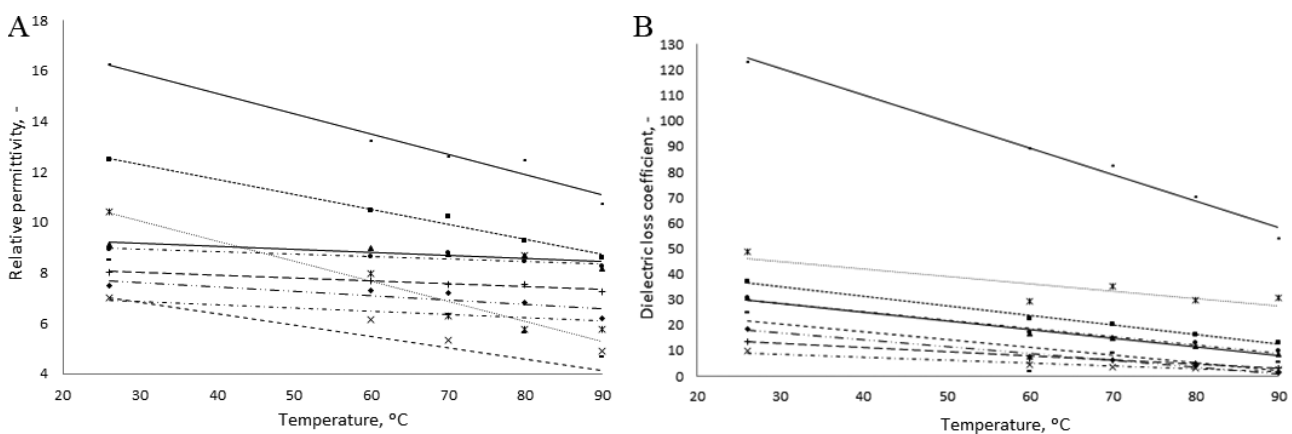

Fig. 3. Relative permittivity $\varepsilon(\mathrm{A})$ and dielectric loss coefficient $\operatorname{tg} \delta(\mathrm{B})$ measured at the frequency $1.1 \mathrm{kHz}$, as affected by thermal treatment temperature-tested honeys: 1: rape; 2: linden flower; 3: phacelia; 4: buckwheat; 5: honeydew; 6: multiflower (harvested in spring); 7: multiflower; 8: heather; 9: willow

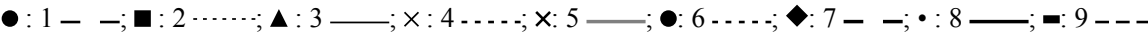

Dielectric loss coefficient tg $\delta$ and relative permittivity $\varepsilon$ values decrease as the thermal treatment temperature increases (Fig. 3). Maximum values of $\operatorname{tg} \delta$ and $\varepsilon$ are observed when honey was not heated at all. In the case of $\operatorname{tg} \delta$ these values are in average twice the $\operatorname{tg} \delta$ values measured for honey overheated up to $90^{\circ} \mathrm{C}$.

Correlation coefficient between dielectric honey parameters measured at the frequency $1.1 \mathrm{kHz}$ and thermal treatment temperature equal $\mathrm{r}=-0.99$ for dielectric loss coefficient $\operatorname{tg} \delta$ and $\mathrm{r}=-0.93$ for relative permittivity $\varepsilon$.

Dielectric features, in particular tg $\delta$, are promising honey parameters for overheating detection. This is in agreement with our previous results, where significant relationship between HMF content and dielectric loss coefficient was found (PENToś \& ŁuCZYCKA, 2017). 
It would be valuable to compare our findings with the results obtained by other authors referring honeys of other botanical and geographical origin. Unfortunately, to the best of authors' knowledge, no other scientific reports concerning the relative permittivity or dielectric loss coefficient measured at frequency below $1 \mathrm{MHz}$ used as honey overheating indicator can be found in prior literature. Nevertheless, some authors pointed out the influence of honey thermal treatment temperature on its dielectric features. Guo and co-workers (2011) investigated temperature-dependent dielectric properties of yellow-locust and jujube honey in the frequency range from 10 to $4500 \mathrm{MHz}$. The strong influence of honey thermal treatment temperature on complex dielectric permittivity of acacia honey in the frequency range from $20 \mathrm{~Hz}$ to $2 \mathrm{MHz}$ was reported by PASZKOWSKI and co-workers (2014). However, the maximum temperature of heating up was $35^{\circ} \mathrm{C}$, and overheating with negative impact on honey quality did not occur during experiments.

\section{Conclusions}

Values of relative permittivity $\varepsilon$ and dielectric loss coefficient tg $\delta$ decrease with increasing thermal treatment temperature. This effect is particularly visible in the frequency range from $650 \mathrm{~Hz}$ to $4 \mathrm{kHz}$. Both these dielectric parameters, in particular dielectric loss coefficient, can be potentially used as honey overheating indicators. The proper frequency range for honey overheating assessment is $1-4 \mathrm{kHz}$. Measurement results at frequencies below $1 \mathrm{kHz}$ can be incorrect due to specific behaviour of biological material placed in electromagnetic field.

This study was performed as part of a project supported by Polish National Science Centre (grant no. N N313 766640).

\section{References}

BABACAN, S. \& RAND A.G. (2007): Characterization of honey amylase. J. Food Sci., 72, C50-C55.

Bogdanov, S., Jurendic, T., Sieber, R. \& Gallmann, P. (2008): Honey for nutrition and health: A review. J. Am. Coll. Nutr., 27, 677-689.

Bogdanov, S., Martin, P., Lüllmann, C. ... \& Ivanov, T. (1997): Harmonised methods of the European Honey Commission. Apidologie, extra issue, 3-59.

Bonvehi, J.S., Torrento, M.S. \& Raich, J.M. (2000): Invertase activity in fresh and processed honeys. J. Sci. Food Agr., 80, 507-512.

Chaikham, P., Kemsamasd, V. \& Apichartsrangkoon, A. (2016): Effects of conventional and ultrasound treatments on physicochemical properties and antioxidant capacity of floral honeys from Northern Thailand. Food Bioscience, 15, 19-26.

Chaikham, P. \& Prangthip, P. (2015): Alteration of antioxidative properties of longan flower-honey after high pressure, ultra-sonic and thermal processing. Food Bioscience, 10, 1-7.

Codex Alimentarius Commission (2001): Codex standard 12. Revised Codex Standard for Honey, Standards and Standard Methods, 11.

Da Silva, P.M., Gauche, C., Gonzaga, L.V., Costa, A.C. \& Fett, R. (2016): Honey: Chemical composition, stability and authenticity. Food Chem., 196, 309-323.

Escriche, I., Kadar, M., Juan-Borras, M. \& Domenech, E. (2014): Suitability of antioxidant capacity, flavonoids and phenolic acids for floral authentication of honey. Impact of industrial thermal treatment. Food Chem., 142, $135-143$.

FAuZI, N.A., FARID, M.M. \& Silva, F.V. (2014): High-pressure processing of manuka honey: Improvement of antioxidant activity, preservation of colour and flow behaviour. Food Bioprocess. Tech., 7, 2299-2307. 
Guo, W., Liu, Y., Zhu, X. \& WANG, S. (2011): Temperature-dependent dielectric properties of honey associated with dielectric heating. J. Food Eng., 102, 209-216.

Guo, W., Zhu, X., Liu, Y. \& Zhuang, H. (2010): Sugar and water contents of honey with dielectric property sensing. J. Food Eng., 97, 275-281.

Karabournioti, S. \& Zervalaki, P. (2001): The effect of heating on honey HMF and invertase. Apiacta, 36, 177181.

Karuppuswami, S., Kaur, A., Arangali, H. \& Chahal, P. (2017): A hybrid magnetoelastic wireless sensor for detection of food adulteration. IEEE Sens. J., 17, 1706-1714.

Kavapurayil, J.B., Karalam, S. \& Chandran, R.P. (2014): Analysis of physicochemical, biochemical, and antibacterial properties of Indian honey samples with special reference to their non-conformity. Acta Alimentaria, 43, 9-18.

KowALSKI, S. (2013): Changes of antioxidant activity and formation of 5-hydroxymethylfurfural in honey during thermal and microwave processing. Food Chem., 141, 1378-1382.

Paszkowski, B., Wilczek, A., Szyplowska, A., Nakonieczna, A. \& Skierucha, W. (2014): A low-frequency sensor for determination of honey electrical properties in varying temperature conditions. J. Food Eng., 138, 17-22.

Pentoś, K., ŁuczycKa, D. \& Kapłon, T. (2015): The identification of relationships between selected honey parameters by extracting the contribution of independent variables in a neural network model. Eur. Food Res. Technol., $241,793-801$.

Pentoś, K. \& ŁuczycKa, D. (2017): Dielectric properties of honey: the potential usability for quality assessment. Eur. Food Res. Technol., 244(5), 873-880.

Polish Standard (1988): Miod pszczeli (Honey). Wyd. Normalizacyjne, PN-88/A-77626

SAmborska, K. \& Czelejewska, M. (2014): The influence of thermal treatment and spray drying on the physicochemical properties of Polish honeys. J. Food Process. Pres., 38, 413-419.

Saxena, S., Gautam, S. \& Sharma, A. (2010): Physical, biochemical and antioxidant properties of some Indian honeys. Food Chem., 118, 391-397.

Silvis, I.C., Van Ruth, S.M., Van Der Fels-Klerxx, H.J. \& Luning, P.A. (2017): Assessment of food fraud vulnerability in the spices chain: An explorative study. Food Control, 81, 80-87.

Turhan, I., Tetik, N., Karhan, M., Gurel, F. \& Tavukcuoglu, H.R. (2008): Quality of honeys influenced by thermal treatment. LWT - Food Sci. Technol., 41, 1396-1399.

Valantina, S.R., Angeline, D.R., Uma, S. \& Prakash, B.G. (2017): Estimation of dielectric constant of oil solution in the quality analysis of heated vegetable oil. J. Mol. Liq., 238, 136-144. 